\title{
Predation bite-marks on a peirosaurid crocodyliform from the Upper Cretaceous of Neuquén Province, Argentina
}

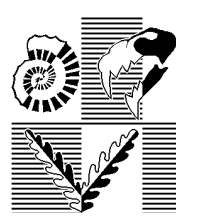

\author{
Lucas Ernesto FIORELLI ${ }^{1}$
}

\begin{abstract}
Bite marks and injuries caused by intraspecific predation or aggressive social behavior are uncommon in fossil vertebrates, and in the fossil record of suchian archosaurs they are extremely unusual. A peirosaurid crocodyliform collected from the Upper Cretaceous beds of the Neuquén Group (northern Patagonia, Argentina) shows abundant bite marks and injuries. These injuries are spread across all the preserved parts of the specimen, with the highest concentration of bite marks, perforations and breakage in the caudal region. Characteristics of these injuries are analyzed, and their possible origin and related taphonomic aspects are assessed. Results indicate that the injuries were not produced by intraspecific fighting, but probably by the predating action of a theropod dinosaur.

Resumen. MARCAS DE PREDACIÓN EN Un CROCODILIFORME PEIROSAURIDO DEL CRETÁCICO SUPERIOR DEL NeUQUÉN, ARGENTINA. El hallazgo de marcas de mordeduras y lesiones por predación o comportamiento social agresivo intraespecífico en vertebrados fósiles es poco frecuente. En el registro fósil de arcosaurios suquianos tales evidencias son extraordinarias. Aquí se reporta un crocodiliforme peirosáurido del Cretácico Superior del Grupo Neuquén (norte de Patagonia, Argentina) con abundantes marcas de mordeduras y lesiones. Estas heridas están localizadas en todas las partes preservadas del espécimen, con una alta concentración de mordeduras, perforaciones y roturas en la región caudal. En el presente trabajo, se analizan las características de las lesiones, y también sus posibles causas y los aspectos tafonómicos relacionados. Los resultados muestran que las mordeduras fueron hechas por la acción de un predador y no por peleas intraespecíficas.
\end{abstract}

Key words. Bite marks. Predation. Peirosaurid. Upper Cretaceous. Neuquén.

Palabras clave. Mordeduras. Predación. Peirosáurido. Cretácico Superior. Neuquén.

\section{Introduction}

Bite marks and injuries produced by predation and scavenging in vertebrate fossils are uncommon and only a few cases are well documented (Erickson and Olson, 1996; Chure et al., 1998; Frey et al., 2002; Everhart, 2005; Reisz and Tsuji, 2006; Bianucci et al., 2010; Hone et al., 2010). Even less common are cases in which the bite injuries are caused by intraspecific and cofamilial aggressive social behavior (Molnar and Farlow, 1990; Sereno and Novas, 1993; Tanke and Currie, 1998; Bell and Currie, 2009). Cases applicable to crocodylomorphs are also limited, with only a few examples recorded in fossil members of this group (Gilmore, 1946; Buffetaut, 1983; Sawyer and Erickson, 1998; Frey et al., 2002). A case of injuries and bite marks produced on the tail of a

${ }^{1}$ Centro Regional de Investigaciones Científicas y Transferencia Tecnológica de La Rioja, Entre Ríos y Mendoza s/n, 5301 Anillaco, La Rioja, Argentina.lfiorelli@crilar-conicet.com.ar

@Associación Paleontológica Argentina specimen of the crocodyliform Baurusuchus pachecoi Price, 1945, from the Adamantina Formation, Bauru Basin (Brazil), was recently reported (Avila et al., 2004). These authors argued that such bite marks were produced by cospecific combat.

Ethology and social behavior of extant crocodylians is more complex than that of other non-archosaurian reptiles (Avila et al., 2004). Many ethological traits, a combination of sensory signals (olfactory, visual, and acoustic), and several corporal postures and social displays are used as warnings before escalation to physical intraspecific aggression occurs (Hunt, 1977; Garrick et al., 1978; Vliet, 1989; Thorbjarnarson and Hernández, 1993; Pough et al., 1998; Senter, 2008). Injuries are caused frequently when for some reason - e.g., disputes for food or territory, dominance fights during reproductive period and courtship behavior, etc. - fighting takes place (Cott, 1961; Hunt, 1977; Vliet, 1989, 2001a, 2001b; Senter, 2008). Adult or subadult extant crocodilians have virtually no natural predators. However, crocodilian nests, neonates and juveniles are predated by mammals, birds, fishes, 
snakes, turtles, and even other crocodilians (Scott, 2004). As adult members of this group represent the top predators in their trophic environments, cases in which they have been attacked by other predators have been very rarely recorded.

Herein I report a peirosaurid crocodyliform from the Santonian Bajo de la Carpa Formation in Neuquén Province, Argentina (Bonaparte, 1991; Fiorelli et al., 2007), with numerous injuries, perforations, breakage, and bite marks. These injuries are present throughout most of the preserved parts of the specimen being more frequent in the caudal section.

\section{Material and methods}

The specimen described here, MUCPv-27 (figure 1.1-1.8), represents a new species of a still unnamed peirosaurid crocodyliform (Fiorelli et al., 2007). Bonaparte (1991) briefly described this specimen and suggested that it would represent a taxon closely related to Araripesuchus Price, 1959. Nevertheless, a recent review of MUCPv-27 stated that it would not represent a form closely related to the Notosuchia, but instead exhibits affinities with neosuchian peirosaurids (Fiorelli et al., 2007). Available fragmentary remains include many elements in good state of preservation but most of the fossil was lost (probably owing to predation). Preserved elements of MUCPv27 (figure 1.1-1.8) include cranial remains, nine dorsal vertebrae, some articulated appendicular elements, numerous presacral osteoderms, and an almost complete caudal region that is fully enclosed by osteoderms. Materials were photographed, drawn, and different digital programs were used for the analysis and design of the images and to highlight specific anatomical aspects.

Abbreviations. MUCP, Museo de Geología y Paleontología, Universidad Nacional del Comahue, Neuquén, Argentina. MUCPv-27 is currently housed at the Centro Paleontológico Lago Barreales -CePaLB-, State Route \#51, Km 65, Neuquén Province, Argentina.

\section{Locality and horizon}

Specimen MUCPv-27 comes from beds exposed within the Campus of the University of Comahue, in the city of Neuquén $\left(38^{\circ} 56^{\prime} 25^{\prime \prime} \mathrm{S}-68^{\circ} 3^{\prime} 10^{\prime \prime} \mathrm{W}\right.$ ) (figure 2.1). In this area, the outcrops are referred to the Bajo de la Carpa Formation, Río Colorado Subgroup, Neuquén Group (middle-upper Santonian; Leanza et al., 2004) (figure 2.2). Unlike other sections in the basin, the rocks of this formation in the city of Neuquén were deposited in fluvial and aeolian systems (Sánchez et al., 2006). Moreover, the arid and dry continental climate was dominated by aeolian deposition, creating big dunes and inter-dune lagoon basins skirted by fluvial deposits, crisscrossed by streams and seasonal or ephemeral water bodies. The horizon in which the fossil was found is composed of coarse-grained, light violet to pink sandstones of fluvial origin.

\section{Fauna of the Bajo de la Carpa Formation}

Various outcrops of the Bajo de la Carpa Formation have yielded a rich fossil vertebrate assemblage (figure 2.2), including the remains of an indeterminate titanosaurid (Chiappe and Calvo, 1994; Parras and González Riga, 2001), cf. Laplatasaurus Huene, 1929 (Leanza et al., 2004), and the peculiar beaked sauropod Bonitasaura salgadoi Apesteguía, 2004, found at the locality known as La Bonita, in Río Negro Province. The theropod dinosaur fauna is also diverse, including the small abelisauroid theropod Velocisaurus unicus Bonaparte, 1991, found in Neuquén (also in the Campus of the University of Comahue). Recently, the presence of carnotaurine abelisaurid theropods was reported from the top of the unit in the La Invernada region, in northern Neuquén (Porfiri and Calvo, 2006), and also at Paso Córdova (Río Negro Province) (Ezcurra and Méndez, 2009). Aditionaly, remains of indeterminate theropods coming from the Auca Mahuida region (Neuquén Province) were considered by Coria and Arcucci (2004) to be large basal tetanurans related to carcharodontosaurids. Porfiri et al. (2008) reported from Tratayén (Neuquén Province) an articulated postcranium belonging to an allosauroid related to the Carcharodontosauria (sensu Benson et al., 2009). Coelurosaurian dinosaurs are also common and relatively well-known, such as the alvarezsaurids Alvarezsaurus calvoi Bonaparte, 1991 (Campus of the University of Comahue) and Achillesaurus manazzonei Martinelli and Vera, 2007 (Paso Córdova), the enantiornithine Neuquenornis volans Chiappe and Calvo, 1994, and the basal ornithuromorph Patagopteryx deferrariisi Alvarenga and Bonaparte, 1992 (both in the Campus of the University of Comahue). Also, bird egg-clutches with embryos (Schweitzer et al., 2002) (Campus of the University of Comahue), dinosaur eggs related to Megaloolithus patagonicus Calvo et al., 1997 (south of Neuquén city), and remains of the snake Dinilysia patagonica Woodward, 1901 (Campus of the University of Comahue). In addition, the chelid Lomalatachelys neuquina Lapparent de Broin and de la Fuente, 2001, comes from Loma de la Lata, in Neuquén Province (de la Fuente, 2007) and constitutes a common faunal element.

Crocodyliforms are an important faunal compo- 


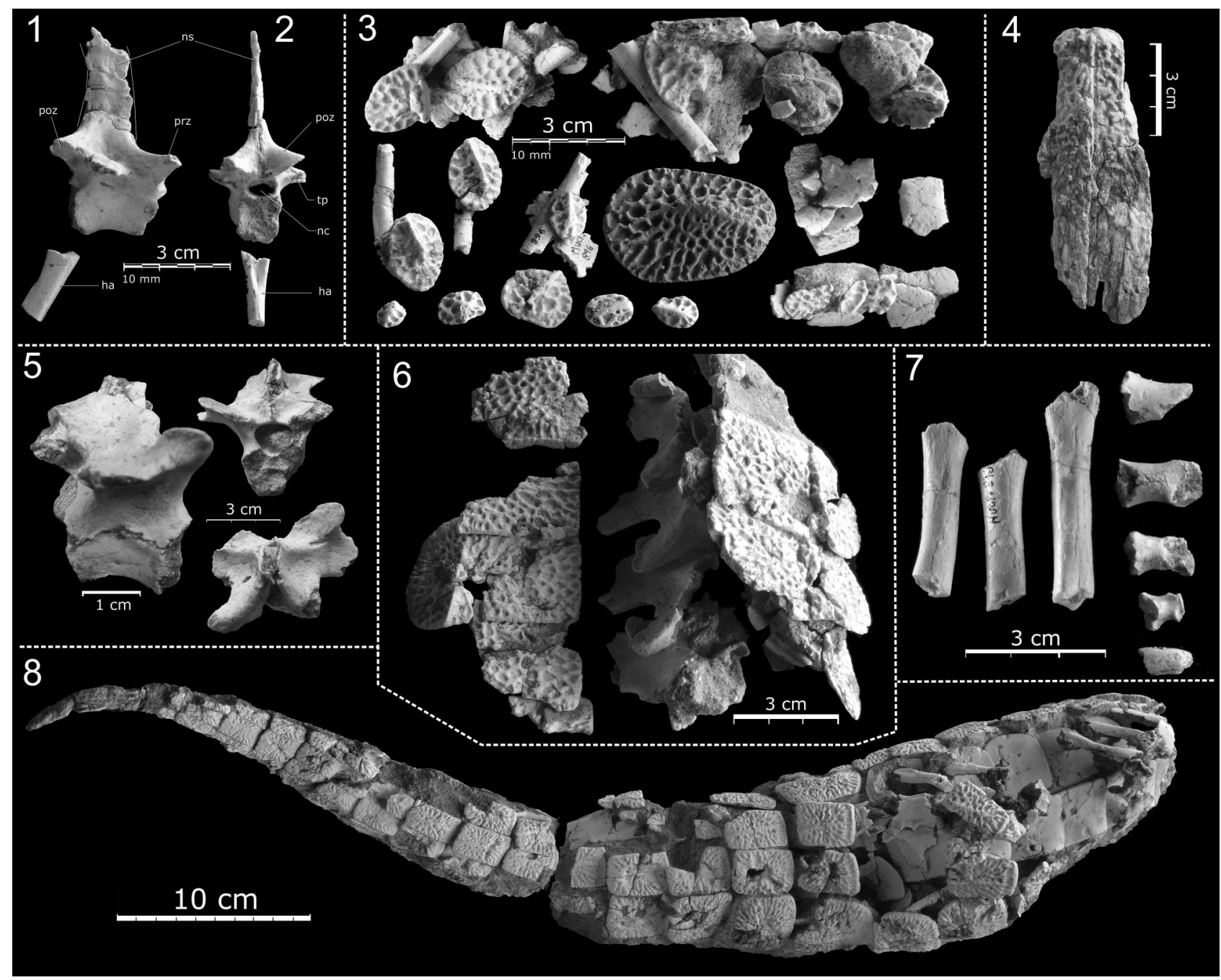

Figure 1. Some elements of the MUCPv-27 peirosaurid. 1 and 2, caudal vertebrae in right lateral (1) and posterior (2) views; 3, several armor pieces, osteodermal plates of the trunk and ribs fragments; 4 , fragment of the snout showing both nasals; 5 , dorsal vertebra; $\mathbf{6}$, articulated middle dorsal vertebrae and plates; 7 , indeterminate appendicular elements; 8 , very complete caudal region showing disposition of the armor on the tail / algunos elementos del peirosaurido MUCPv-27 1 y 2, vértebra caudal en vista lateral derecha (1) y posterior (2); 3, varias piezas de la dermostea, osteodermos del tronco y restos de costillas; $\mathbf{4}$, fragmento del hocico mostrando ambos nasales; 5 , vértebra dorsal; 6, vértebras dorsales medias y placas articuladas; $\mathbf{7}$, elementos apendiculares indeterminados; 8, región caudal muy completa mostrando la disposición de la dermostea sobre la cola.

nent of the Bajo de la Carpa Formation with Notosuchus terrestris Woodward, 1896, being the most abundant vertebrate from the unit (remains of Notosuchus were found in the Campus of the University and at Paso Córdova). Other crocodyliforms, found in the Campus of the University and at Paso Córdova, are the derived notosuchian $\mathrm{Co}^{-}$ mahuesuchus brachybuccalis Bonaparte, 1991 (Campus of the University), the baurusuchids Cynodontosuchus rothi Woodward, 1896 (uncertain locality), Wargosuchus australis Martinelli and Pais, 2008, and the basal mesoeucrocodylian Neuquensuchus universitas Fiorelli and Calvo, 2007, the last two from the Campus of the University of Comahue.

\section{Brief description of MUCPv-27}

The elongated nasals form the dorsal edge of the external nares and bear deep pits and grooves resembling those of peirosaurids. The median suture is evident and straight. The lateral edges of the nasals are subparallel to each other. As in other peirosaurids, the internal surface does not bear a nasal septum (figure 1.4).

The degree of preservation of some of the postcranial materials is exceptional, as most of the osteoderms are preserved in natural articulation (figures 1.6, 3.1-3.3). The dorsal region of the vertebral column is short and represented by nine elements, four of which are articulated to each other and to several 

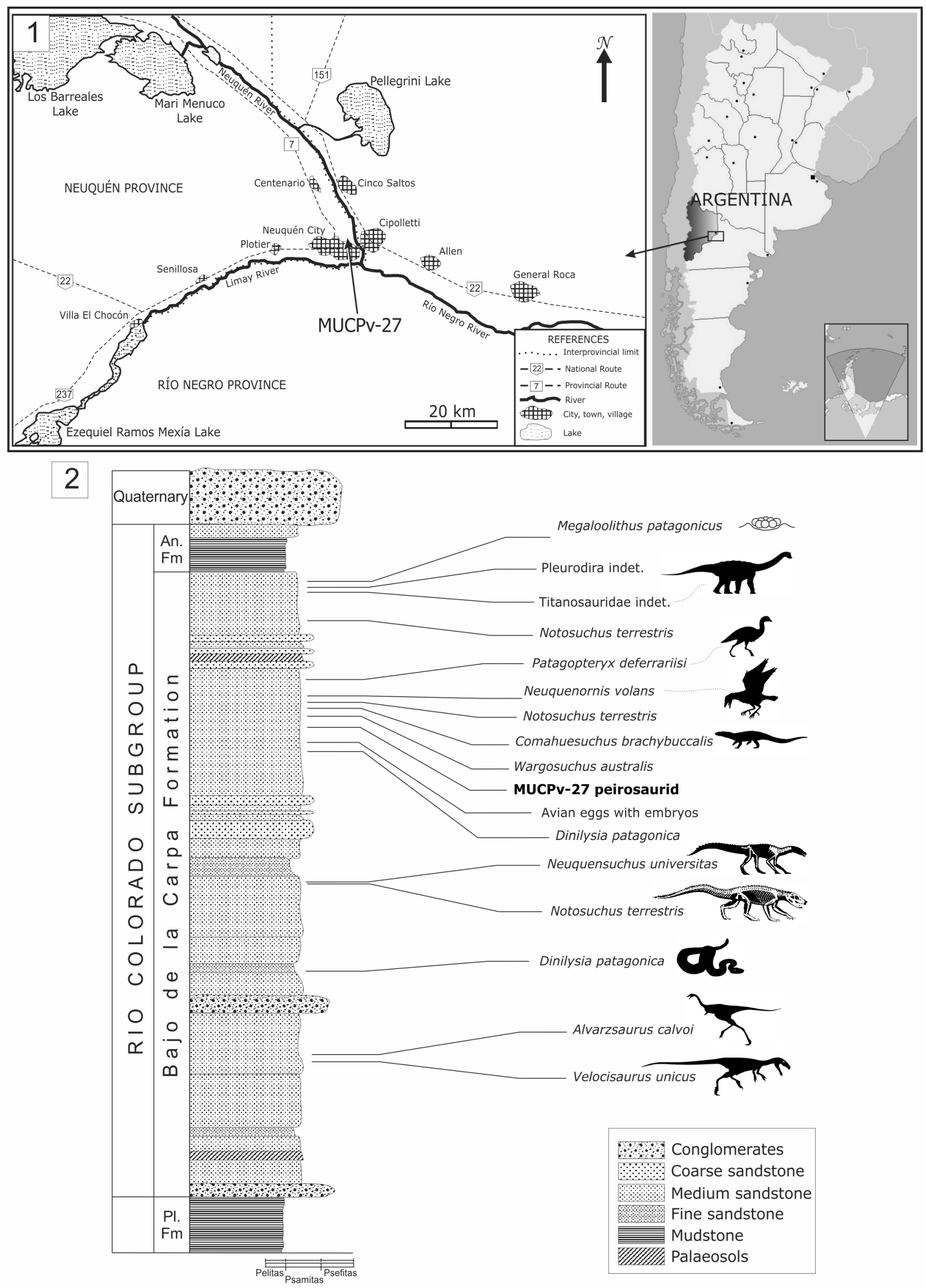


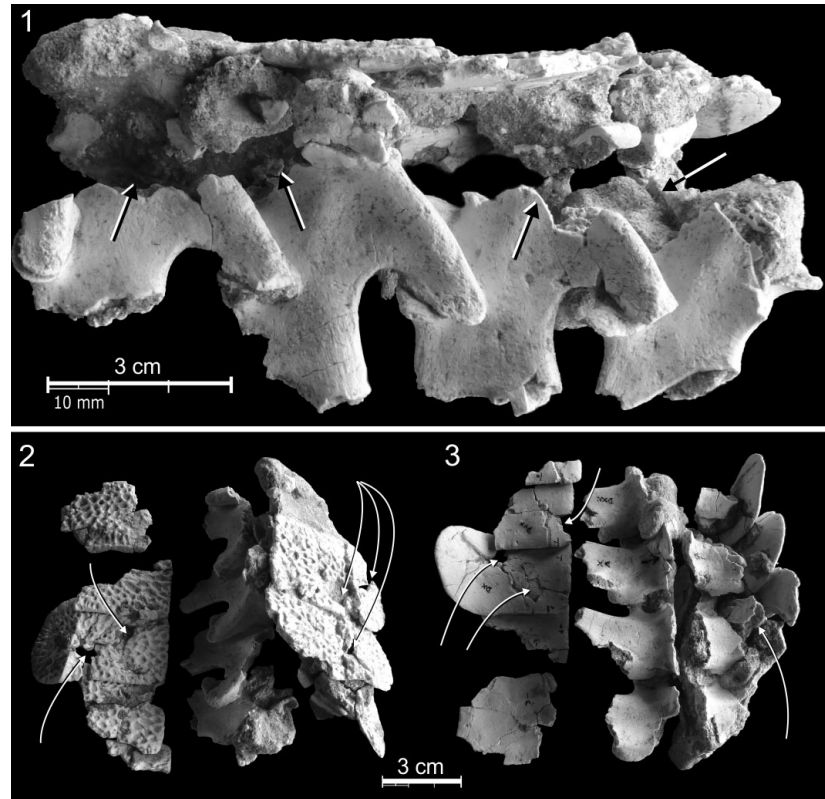

Figure 3. Dorsal vertebrae and articulated trunk osteoderms of the MUCPv-27 peirosaurid showing several bite marks. 1, left lateral view; 2 , dorsal view; 3 , ventral view. The black and white arrows indicate puncture marks and injuries present in the specimen / vértebras dorsales y osteodermos articulados del tronco del peirosáurido MUCPv-27 mostrando diversas marcas de mordedura. 1, vista lateral; $\mathbf{2}$ vista dorsal; $\mathbf{3}$, vista ventral. Las flechas negras y blancas indican las marcas de perforaciones y lesiones presentes en el espécimen.

paravertebral dorsal osteoderms. Seven dorsal vertebrae lack their centra whereas the other two dorsal vertebrae have complete spool-shaped centra with a completely closed neurocentral suture. Brochu (1996) showed that neurocentral sutures in the extant crocodylian vertebral column close in a posterior-anterior pattern as the animal matures. Moreover, this author used these ontogenetic changes as relative maturity indicators (Brochu, 1996). This pattern was recently confirmed as plesiomorphic for the Pseudosuchia (Irmis, 2007). Although it is impossible to pinpoint the age of the MUCPv-27 peirosaurid (due to lack of histological data), the neurocentral suture closure of the dorsal series could indicate that it was a subadult or adult specimen. These vertebrae are robust, with anteroposteriorly elongated neural spines, and pre- and post-spinal laminae. Caudal vertebrae (figures 1.1-1.2) possess dorsally elongated neural spines, a noticeable development of the pre- and post-spinal laminae, and a ventral groove on the centra, like other peirosaurids (Fiorelli et al., 2007).

The external surfaces of the osteoderms are heavily ornamented by deep pits and grooves and bear a slightly developed ridge (figures 1.3, 1.6). In MUCPv-27 the dorsal osteoderms of the first paravertebral row possess rounded lateral edges (figure 1.6). This character differs from that of other peirosaurids that possess dorsal osteoderms with straight lateral edges (e.g., Uberabasuchus Carvalho et al., 2004). The presacral dorsal osteoderms are preserved in natural articulation, indicating the presence of a single row of parasagittal osteoderms flanked by accessory (rounded) osteoderms (figure 1.3). This morphology contrasts with that of other peirosaurids (e.g., Mahajangasuchus Buckley and Brochu, 1999, and Uberabasuchus Carvalho et al., 2004), suggesting that this poorly studied clade had a highly diversified osteoderm morphology and arrangement. Numerous small osteoderms with complex articulated edges represent elements of the ventral armor (figure 1.3). The caudal osteoderms completely enclose the tail endoskeleton; their general morphology varies according to their location, ranging proximo-distally from subquadrangular to anteroposteriorly elongated elements (figure 1.8).

\section{Bite marks in the peirosaurid MUCPv-27}

Virtually all the preserved elements of MUCPV27 carry clear signs of injury and bite marks, mainly in the osteoderms and vertebrae that compose the caudal section (figure 1.8). More than 70 bite marks, punctures, breakage points, and other related damage are present in the preserved parts of the specimen. All marks are in the postcranial area, which is not surprising due to their fragmentary nature and the lack of preservation of more skull material.

The articulated dorsal section presents some indications of bite marks and represents a very affected and damaged section. It cannot be established whether this damage was due to predation or to later erosion, although the biostratinomic processes affecting the material were more important than either the diagenetic or erosional processes (see below, Taphonomic Considerations). In any case, the

Figure 2. Locality and horizon. 1, map of Argentina and the Comahue region showing the site where MUCPv-27 was collected; 2, stratigraphic column of the Bajo de la Carpa Formation, Neuquén Group (taken and modified from Chiappe and Calvo, 1994, and Leanza et al., 2004) showing the diverse biota found in the outcrops of this formation mainly in the University Campus / localidad y horizonte. 1, mapa de Argentina y la región del Comahue señalando el sitio donde fueron recolectados los materiales de MUCPv-27; 2, columna estratigráfica de la Formación Bajo de la Carpa, Grupo Neuquén (tomado y modificado de Chiappe y Calvo, 1994, y Leanza et al., 2004) mostrando la variada biota hallada en los afloramientos de esta formación, especialmente en el campus universitario. 
greatest damage in the presacral section is observed ventrally, where the vertebrae lack their respective centra. Additionally, almost all neural apophyses and neural spines are damaged at their distal ends and several tiny bony fragments (figures 3.1-3.3) were found during preparation. Diverse breakage marks and circular perforations filled by sediment are present on the articulated dorsal paravertebral osteoderms (figures 3.1-3.3, 4.1-4.3). The perforations vary in diameter $(\sim 5-10 \mathrm{~mm})$ and present a singular disposition. All perforations are arranged linearly along the axis of the animal, in each osteoderm from the right side and located medial to the osteodermal keel (i.e., carina dermostealis) (figures 3.2, 4.2). In the corresponding preserved paravertebral osteoderms of the left side, the same and very characteristic linear arrangement can be observed (figure 3.1-3.3, 4.3). This alignment of injuries along both sides of the trunk could indicate a single bite made by larger predator on the back of MUCPv-27.

Diverse perforations and breakage marks can be observed on the external surface of the articulated osteoderms, suggesting that the perforations were made from the outside towards the inside. Moreover, the internal surface of some osteoderms displays unhealed bony elevations or incisions and without fossilized connective tissue (figures 5.3, 6.4-6.5) - underneath the external bite marks. These traits cannot be observed on the right side osteoderms. Breakage marks in the trunk osteoderms are also filled by sediment, indicating that the dorsal section was covered with sediments subsequent to the action of the predator. Such taphonomic features suggest high fragmentation was produced by predation, before burial of the specimen. Some of the isolated osteoderms exhibit very sharp and acute punctures, as well as rounded and circular marks (figures 4.3, 5.2-5.3).

The tail section possesses dozens of bite marks, injuries, perforations, punctures, breakage marks and "scratches". The circular and aligned bite marks are present on both sides of the tail (figures $1.8,5.1-5.7,7.1-7.2)$. The articulated caudal region is crushed in a direction which is aligned with the axes that join the ventral and dorsal bite marks. This suggests that the crushing of the caudal region may have been produced by one single bite delivered by the predator. Almost all the bony elements of the tail show signs of damage, mainly in the armor (figures 1.8, 5.1-5.7, 6.1-6.3). The most important damage is perforations directed from the outside towards the inside of the armor plates. Most of these perforations are quite irregular on the osteoderm external surface (range of diameter $=3-20 \mathrm{~mm}$ ). However, the corresponding internal marks are ex- tremely characteristic, with obvious sediment infilling both perforations and cracks radiating from them (figures 5.3, 5.6, 6.5). This clearly indicates that the pressure exerted by the jaws of the predator on the caudal section was directed from outside toward the center. Another important characteristic observed is that all perforations are arranged longitudinally along the external surface of the tail (at least, three rows of punctures on each side of the tail). This supports the idea of a bite mark produced by a predator that bit the tail multiple times. In addition, numerous caudal osteoderm fragments display breakage marks, which were posthumously filled by sediment. Diverse caudal osteodrems were found disarticulated, but associated with the tail; these exhibit considerable puncturing and breakage identical to that observed in the rest of the osteodrems (figure 6.4-6.7).

All caudal vertebrae and haemal arches remain articulated. Like the armor, these are extraordinarily well-preserved, although they have been affected by predatory action too, a fact revealed by numerous bite marks observable throughout the series. For each bite mark, punctures and deeper breakage marks are correlated with the breakage between the vertebraemainly in the centra-and haemal arches (figures 5.15.2, 6.1-6.3). The main breakage and punctures occurred in between the vertebrae, because the extremities of the vertebral centra are cracked (infillings of sediment with small particles of bone; figure 6.3). Moreover, the neural spines and apophyses present considerable damage and breakage, because of collapse of the armor onto the axial skeleton possibly by the mandibular pressure exerted.

\section{Discussion}

The punctures and breakage displayed in the MUCPv-27 peirosaurid correspond clearly to bite marks and injuries produced by a predator. However, it cannot be determined whether the injuries caused the death of the specimen or if they just represent carrion biting. In any case, these two ideas are not mutually exclusive and a combination of both cannot be rejected. The observed features however, reject the hypothesis that the multiple bite marks and injuries were the result of aggressive intraspecific fights and/or agonistic social behavior including biting related to rivalry between males (e.g., territoriality, reproduction, food). This conclusion is drawn from the fact that the bite marks and punctures are numerous (more than 70), producing considerable trauma to the organism. Crocodilian males normally use dominance advertisement postures and headslapping at the water surface (Garrick et al., 1978; 

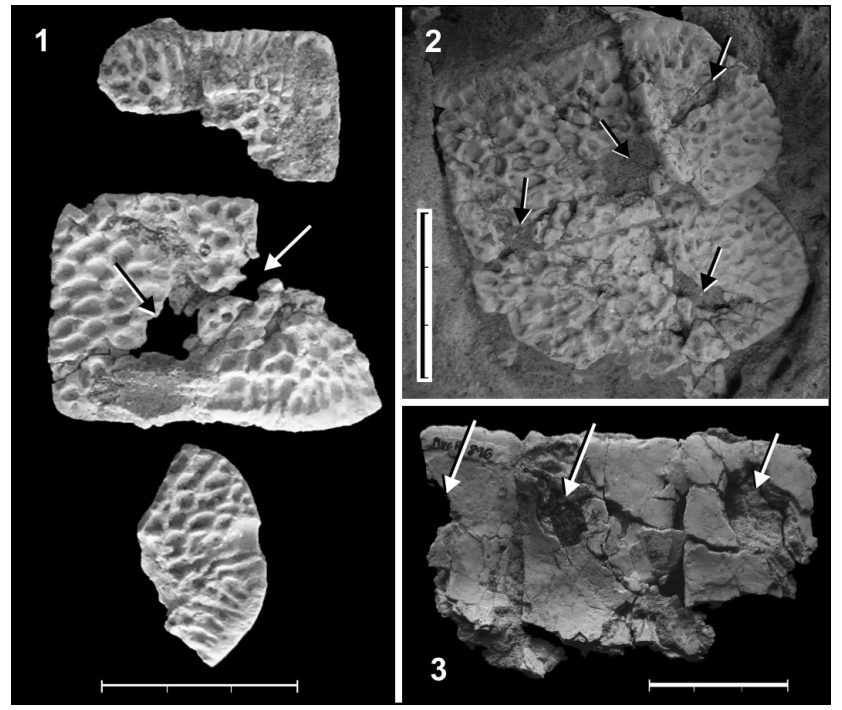

Figure 4. Several isolated and articulated osteoderms of trunk of MUCPv-27 with punctures and bite marks. 1, isolated osteoderm fragments showing some punctures in dorsal view; 2 , two articulated paravertebral osteoderm plates from the right side of trunk with aligned marks in dorsal view; 3 , three paravertebral osteoderm plates from the left side of trunk with circular aligned marks in ventral view. The black and white arrows indicate the puncture marks and injuries present in the specimen. Scale bars $=3 \mathrm{~cm} / \mathrm{al}$ gunos osteodermos del dorso de MUCPv-27 aislados y articulados con perforaciones y marcas de mordidas. 1, vista dorsal de fragmentos de osteodermos aislados que muestran perforaciones; $\mathbf{2}$, vista dorsal de dos osteodermos paravertebrales articulados del sector derecho del tronco con marcas alineadas; $\mathbf{3}$, vista ventral de tres osteodermos paravertebrales del lado izquierdo del tronco con marcas circulares alineadas. Las flechas negras y blancas indican las marcas de mordeduras y heridas presentes en el espécimen $/$ escala $=3 \mathrm{~cm}$.

Vliet, 1989, 2001a, 2001b; Pough et al., 1998; Senter, 2008) in intraspecific conflicts. However, there are eventually fights between males which cause some damage, but rarely end in death of the animal (Cott, 1961; Hunt, 1977). As was hypothesized by Avila et al. (2004), social behaviors observed in extant representatives of the group were already present in more basal crocodyliforms such as baurusuchids. This suggests that these behaviors appeared early in the evolutionary history of the group. According to Cott (1961), in studies performed on specimens of the Nile crocodile (Crocodylus niloticus Laurenti, 1768), the majority of injuries were produced by individuals of the same species - between rival males or attacks by potential cannibals - and $70 \%$ of these occurred on the tail (Avila et al., 2004). These marks tend to be shallow and are unlikely to be fatal.

Injuries inflicted on most postcranial elements of specimen MUCPv-27 are not consistent with intraspecific interactions such as recorded by Cott, (1961) or Avilla et al. (2004), as they are much deeper and affect both dorsal and caudal vertebrae. This does not rule out the possibility that this species engaged in intraspecific interactions involving non-lethal biting, but the present specimen does not provide evidence of such behavior. Instead, bite marks found on MUCPv-27 suggest the attack of a significantly larger animal, able to inflict lethal wounds on this large-sized peirosaurid ( 3-4 $\mathrm{m}$ in length).

\section{Sedimentological and taphonomical considerations}

Outcrops of the Bajo de la Carpa Formation at the University Campus quarry are composed of yellow quartzose sandstones, with poorly sorted subangular to subrounded grains, claystone matrix, calcareous cement, and light ferric color (Garrido, 2000). During the Santonian-Campanian, the Bajo de la Carpa Formation biotope comprised a wide basin with fluvial phases and extensive flood plains. This fluvial system with very low sinuosity and abundant sand load was also characterized by a complete absence of mudstones (Garrido, 2000). Moreover, the arid and dry continental climate was dominated by aeolian deposition, creating large dunes and interdune lagoon basins skirted by fluvial deposits, crisscrossed by streams with the occurrence of seasonal flooding (Caldwell and Albino, 2001).

Sánchez et al. (2006) characterized the sedimentary and paleoenvironmental sequences of the outcrops in the neighborhood of Neuquén city by means of a very complete and detailed lithostratigraphic section of the Bajo de la Carpa Formation at the University Campus quarry. They determined that this unit is represented - from base to top - by deposits of ephemeral fluvial systems followed by integrated fluvio-aeolian systems. The former correspond to canalized flows during maximum discharge episodes, with fine- and medium-grained sandstones rich in quartz and abundant yellow to pink silt - clay matrix. These sandstones are found as low angled cross beds. The fluvio-aeolian deposits were developed in a transverse dune field affected by ephemeral fluvial currents in the inter-dune areas, and parabolic dunes that were likely the result of remobilization of the underlying aeolian system, associated with periodic flood events by ephemeral sheet flows. These beds appear as white sandstones with parallel and horizontal lamination (Heredia and Calvo, 2002; Sánchez et al., 2006). Moreover, these authors agree that the extent and geometry of the dune fields responded to climatic variations of short term, fluvial system interference, and oscillations of phreatic levels, low sediment provision, and tectonic factors (Sánchez et al., 2006).

In this unique environment, compared with other Patagonian Cretaceous settings, poor vegetation was influenced by a great seasonality, evidenced by the 

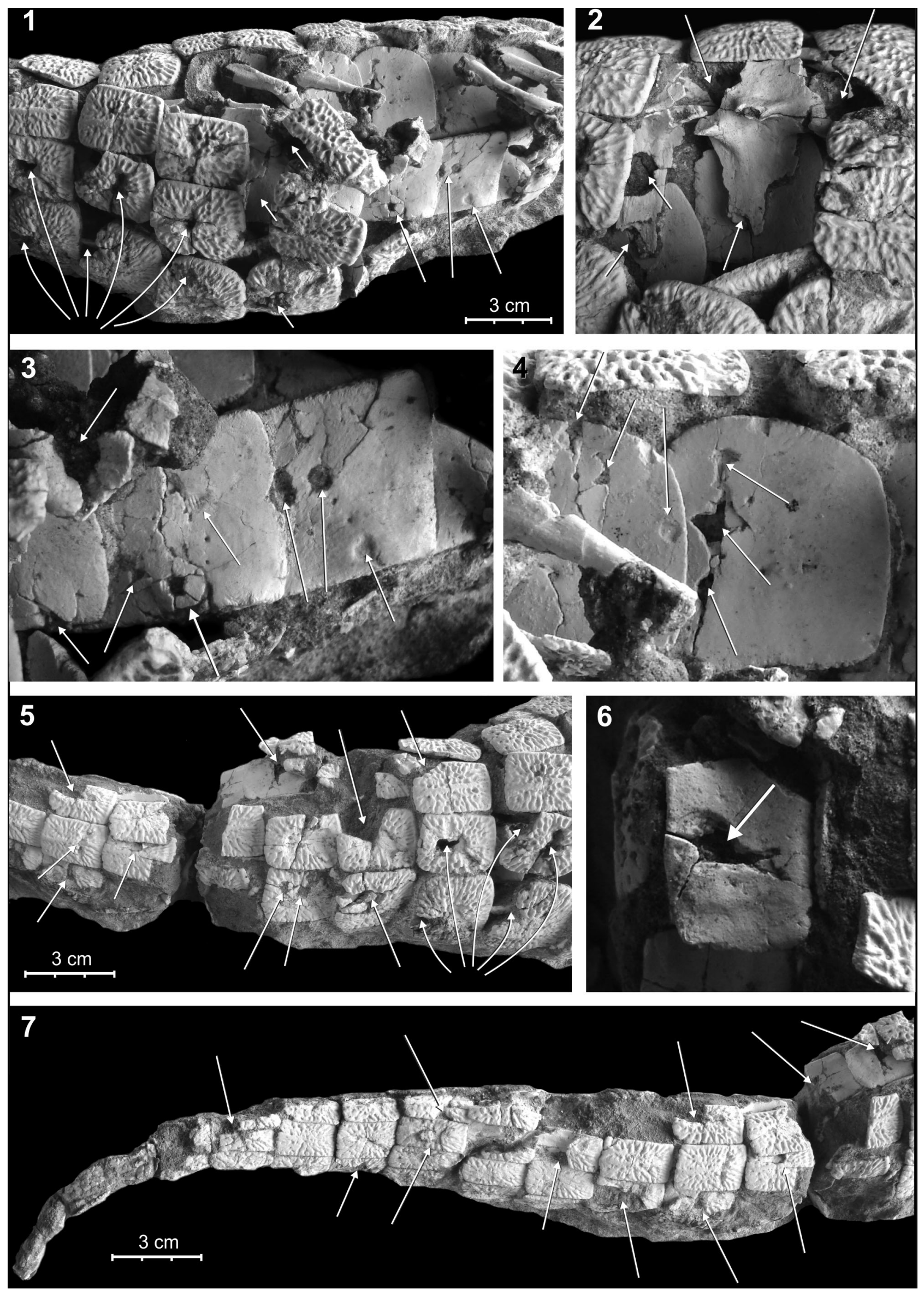

AMEGHINIANA 47 (3), 2010 
discovery of abundant roots and bulbs. Also, insects and pupae chambers are very common (Caldwell and Albino, 2001; Fiorelli et al., 2006).

Despite the arid and relatively extreme conditions prevailing in the paleoenvironment of the University Campus exposures during the Santonian, its taxonomic diversity was high (figure 2.2; see also Fauna of the Bajo de la Carpa Formation section). The vertebrates from the University Campus area were found close to each other, in an area of approximately $40,000 \mathrm{~m}^{2}$ and representing mainly small- to medium-sized ( 0.3-2.0 m) specimens. The largest vertebrate remain from this level is the peirosaurid specimen MUCPv27 , with an estimated body length of 3-4 $\mathrm{m}$. Other vertebrates are not larger than one or two meters, but the bite marks on MUCPv-27 indicate the presence of a larger predatory species.

The general characteristic features exhibited by the MUCPv-27 peirosaurid, reveal that the biostratinomic processes were the most important taphonomic processes. MUCPv-27 was exhumed in a quartzite medium-grained sandstone matrix that is extremely friable and homogeneous. Although biostratinomic attributes (i.e., climatic damage, breakage, accumulated abrasion, transport, predator/scavenger action) tend to increase with the time of sub-aerial exposure, the peirosaurid specimen $\mathrm{MUCPv}-27$ exhibits only bite marks and lacks other taphonomic attributes. The damage produced by one or several predators and the absence of other biostratinomic factors could indicate that the burial occurred shortly after the predation event (which might have produced the death of this animal). Beyond the predation event, no important mechanical or physical transport took place before burial. This is inferred from three important key characteristics:

1) The articulated caudal section presents compression in a direction perpendicular to the longitudinal tooth bite marks and to the inferred bite pressure (figure 7.1). For this reason, we can reject lithostatic forces or deformation/pressure by the sediment.

2) As described before, there are many bony mi- crofragments, with sediment completely filling the spaces produced by the bite marks; this suggests the complete absence of selective transport.

3) The fact that the osteoderms remained articulated and imbricate in both dorsal and caudal sections is evidence that the remains were not eaten and that quick burial, but not transport, followed predation.

On the other hand, several studies demonstrated that vertebrate predators and scavengers modify bones (e.g., Weigelt, 1989; Behrensmeyer, 1978; Hill, 1987; Njau and Blumenschine, 2006). The grooves found on fossil bones can best be attributed to damage by a carnivorous animal since there is no reliable method to differentiate feeding during predation versus scavenging (Barder et al., 2009). According to Farlow and Holtz (2002), distinguishing successful predation events from scavenging on the basis of tooth-marked bones is probably impossible, because the victim cannot recover from either. However, Barder et al. (2009), Chure and Fiorillo (1997), Chure et al. (1998), and Jacobsen (1999), among others, showed that the grooves and repeated rectilinear striae on bones in the fossil record were more probably produced by vertebrate scavengers than active predators. In this regard, the MUCPv-27 peirosaurid does not exhibit parallel grooves or rectilinear striae, indicating that the carcass was not sub-aerially exposed for a long time (which explains the lack of scavenging events after predation).

Disarticulation, breakage, fragmentation, and orientation of bones were therefore most likely generated exclusively by predator action and not by physical and/or weathering mechanics. The action of decomposers produced no significant disarticulation and dismemberment. Activities of arthropod or worm scavenging, and fungal action are rejected or would have been minimal due to the absence of any paleosol and/or bioturbation in the bed where MUCPv-27 was found. Therefore, bacterial action is considered to be mainly responsible for necrolysis and decomposition of the connective tissue after burial. Additionally, no bones exhibit bioerosion, accumulated abrasion, bone surface deterioration or corrosion

Figure 5. MUCPv-27; several views of the articulated tail section showing many bite marks, perforations and injuries. 1, proximal section of tail in left lateral view (the fossil was found on its back with the ventral part facing upwards); 2 , caudal vertebrae fully surrounded by caudal plates in left lateral view, showing the internal damage to the centra and neural spines; 3 , row of right paravertebral caudal plates in inner view with tooth mark and punctures marks in both sides (observe the radial axes born from the central perforation in the left mark); 4, right accessory osteoderm plates of the tail showing numerous linearly arranged perforations; 5 , middle section of the tail; 6, inner side of ventral plate of the middle section of tail with a clear puncture mark; 7, distal section of the tail in the left lateral view. White arrows indicate puncture marks and injuries / MUCPv-27; vistas de la sección caudal articulada mostrando numerosas mordeduras, perforaciones y lesiones. 1, vista lateral izquierda de la sección proximal de la cola (el fósil fue hallado invertido, con la parte ventral hacia arriba); $\mathbf{2}$, vista lateral izquierda de las vértebras caudales rodeadas completamente por osteodermos mostrando los daños internos en los centros y las espinas neurales; 3, vista interna de una hilera de osteodermos paravertebrales caudales del sector derecho con marcas de dientes y perforaciones en ambos lados (obsérvense los ejes radiales que se extienden desde una de las perforaciones); 4, osteodermos accesorios derechos de la cola mostrando numerosas perforaciones alineadas; $\mathbf{5}$, sección media de la cola; $\mathbf{6}$, lado interno de un osteodermo ventral de la sección media de la cola mostrando una perforación muy clara; 7 , vista lateral izquierda de la sección distal de la cola. Las flechas blancas muestran las perforaciones y lesiones. 

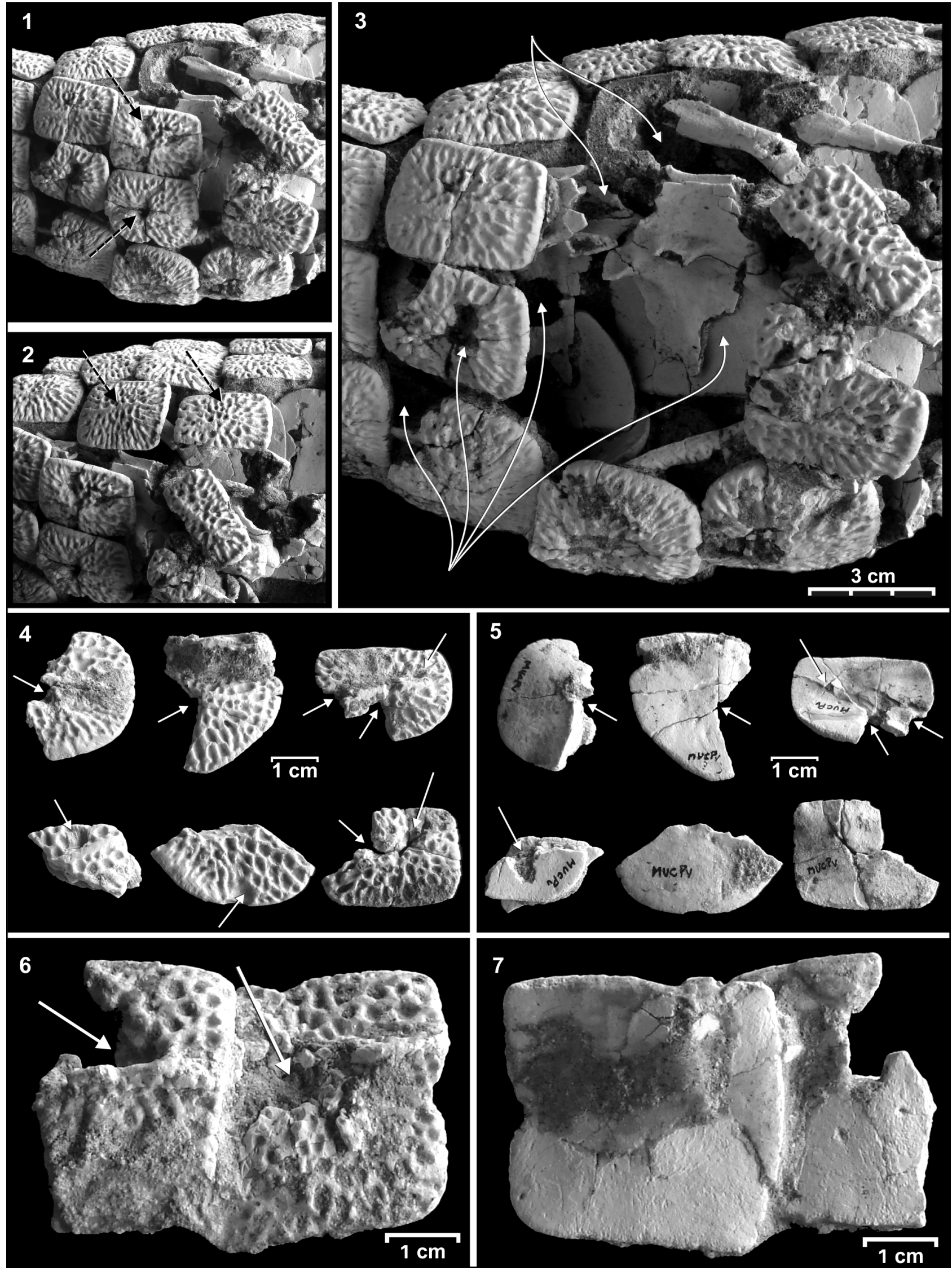

Figure 6. MUCPv-27, tail and osteodermal plates. 1 and 2, middle section of the tail of MUCPv-27 showing puncture and bite marks on the outside; 3 , puncture marks and damage (arrows) in the inner side of the tail -mainly in the caudal vertebrae- when the osteodermal AMEGHINIANA 47 (3), 2010 


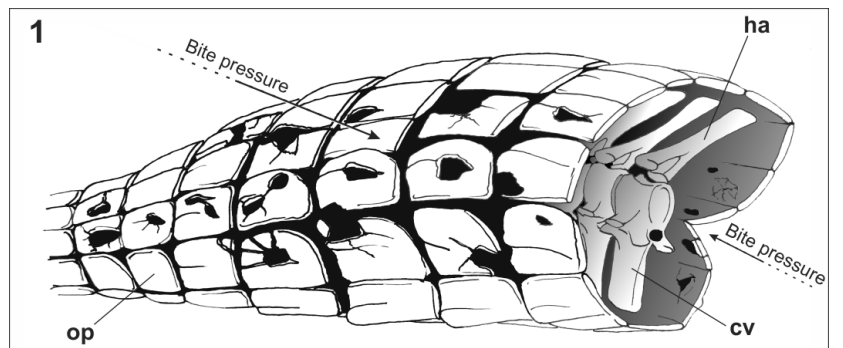

op

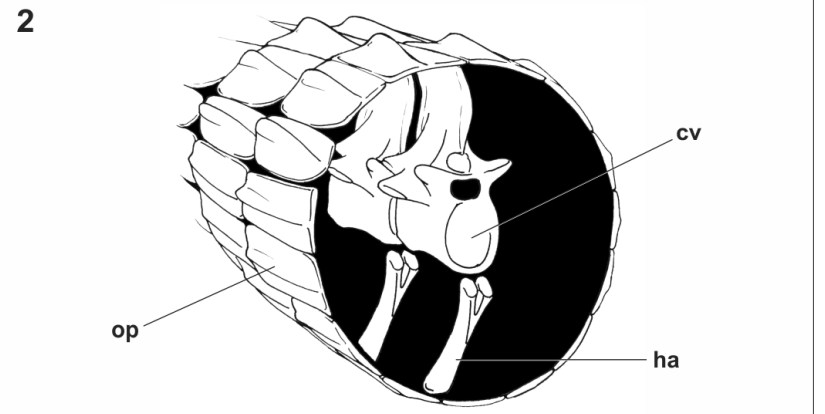

Figure 7. 1, Schematic reconstruction showing the articulated tail of MUCPv-27 as it was found in the sediment-turned up side down- and the injuries and bite pressure (black arrows) on both sides; 2, restoration of the caudal section showing the correct position of tail and the several osteodermal plates completely enclosing the vertebrae. cv, caudal vertebra; ha: hemal arch; op, osteodermal plate / reconstrucción esquemática que muestra cómo fue hallada en el sedimento la cola articulada de MUCPv-27 -con la superficie ventral girada hacia arriba-mostrando las lesiones y la presión de mordida (flechas negras) en ambos lados; 2, restauración de la sección caudal mostrando la correcta posición de la cola y la dermostea encerrando completamente las vértebras. co, vértebra caudal; ha, arco hemal; op, osteodermo.

(dissolution) signals. It is known that weathering increases and bone density decreases with the distance from the channel, so that in distal floodplain facies only scarce and weathered fossils occur (Behrensmeyer, 1978; Smith, 1993; Willis and Behrensmeyer, 1994; Holz and Simões, 2005). In this regard, the sedimentary characteristic of the University Campus area and the homogeneous taphonomic attributes exhibited by MUCPv-27 suggest that this peirosaurid was exposed to weathering for only hours to a few days.

No other vertebrate remains found at the University Campus quarry show significant transport features, but in some cases some disarticulation or dismemberment is present. The quarry yielded frequent and abundant in situ preserved avian egg-clutches (Schweitzer et al., 2002) - some with embryonic re- mains - and numerous articulated or semi-articulated specimens with cranial remains of Notosuchus Woodward, 1896 and Dinilysia Woodward, 1901 (Caldwell and Albino, 2001; Albino and Caldwell, 2003; Pol, 2005; Fiorelli and Calvo, 2008). However, there is no case of preserved soft tissues (e.g., tendons, skin impressions), possibly because the typical quartzitic aeolian medium-grained sandstone from this stratigraphic level directly affects preservation.

Taphonomic analysis indicates that the death of this peirosaurid was a selective event (due to predation), and not caused by subsequent burial, because this represents a local catastrophic episode that also buried other representative vertebrates in the same unit at the University Campus quarry. Although not all the remains found in this quarry are contemporaneous, their taphonomic attributes are highly homogeneous indicating little time averaging.

\section{The identity of the putative predator of MUCPv-27}

In the Bajo de la Carpa Formation, carrying one of the richest and most characteristic vertebrate faunas from the Neuquén Group, there are only two possible predatory or scavenging animals capable of producing such bite marks on a three meter long peirosaurid: a large crocodyliform or a theropod dinosaur. Crocodyliforms dominated this fauna, in which the most conspicuous and abundant faunal element was the notosuchian Notosuchus terrestris Woodward, 1896 (more than 50 specimens found up to now). Although it represents a small- to mediumsized form, recent studies on rostral, dental, cranial and postcranial features led to the conclusion that Notosuchus would have been an important herbivore, specializing in consumption of low-standing and geophytic vegetation (Fiorelli et al., 2006; Fiorelli and Calvo, 2008). Nevertheless, a recent study on the teeth and dental characters of Notosuchus (Lecuona and Pol, 2008) showed differences in diet type and feeding behavior among notosuchians (i.e., Sphagesaurus Price, 1950, and Mariliasuchus Carvalho and Bertini, 1999). Although no particular diet has been inferred for Comahuesuchus brachybuccalis Bonaparte, 1991, its cranial characteristics and small body size (Bonaparte, 1991; Martinelli, 2003) make it obvious that it could not generate large bite

plates indicated in 1 and 2 are removed; 4 and 5, isolated fragments of dorsal and caudal osteodermal plates in external (4) and inner (5) views; 6 and 7, two articulated paravertebral caudal osteodermal plates from the left side in external (6) and inner (7) views. White arrows show puncture marks and injuries / MUCPv-27, cola y osteodermos 1 y 2, sección media de la cola de MUCPv-27 mostrando las perforaciones y mordeduras del lado externo; 3, perforaciones y daños (flechas) en el lado interno de la cola -principalmente en las vértebras caudales- cuando son removidos los osteodermos señalados en 1 y 2; 4 y 5 fragmentos aislados de osteodermos dorsales y caudales en vistas externa (4) e interna (5); 6 y 7, dos osteodermos paravertebrales caudales articulados del lado izquierdo en vistas externa (6) e interna (7). Las flechas blancas indican perforaciones y lesiones. 
marks and cause great injuries. Overall, these typical notosuchians can be rejected as potential predators of the peirosaurid under study. The basal mesoeucrocodylian Neuquensuchus universitas Fiorelli and Calvo, 2007, represents a cursorial and running form of small to medium size. Although cranial remains are not known, Neuquensuchus probably had a small skull ( 100-150 mm), with a morphology resembling that of the skulls of Shantungosuchus Young, 1961, and Sichuanosuchus Peng, 1995 (Fiorelli and Calvo, 2007), which disqualifies this crocodyliform as another potential predator. Further crocodyliforms that coexisted with the peirosaurid specimen MUCP-27 are the baurusuchids Cynodontosuchus rothi Woodward, 1896, and Wargosuchus australis Martinelli and Pais, 2008. These crocodyliforms - in addition to other peirosaurids (perhaps with cannibalistic habits) - could possibly have been the predators or scavengers of specimen MUCPv-27; they were macropredators and strict carnivores that inhabited the same semi-arid paleoenvironment in what is now the University Campus area of Neuquén city. However, the continuous longitudinal bite marks present in the caudal section indicate that the predator that made those marks had a large-sized skull. This observation points further towards the possibility that a large theropod dinosaur was responsible for the bite marks in $\mathrm{MUCPv}-27$. As previously mentioned, several carnivorous dinosaurs are known from the Bajo de la Carpa Formation, although only some of them had large skulls, namely abelisaurids and carcharodontosaurids (Porfiri and Calvo, 2006; Coria and Arcucci, 2004; Porfiri et al., 2008; Ezcurra and Méndez, 2009). The predator that caused the bites did not swallow the tail section after the attack, possibly because of the difficulty of tearing apart and swallowing this armored body part. This can be inferred because the tail was not digested (the specimen does not present abrasion, dissolution or bioerosion), but instead remained articulated after the generation of injuries and bite marks.

\section{Conclusion}

Although social behavior and ethological features of extant crocodyliforms are very complex (combination of sensorial aspects, corporal postures and social displays), it has been hypothesized that these characters were acquired early in the evolution of the group (Avila et al., 2004). However, these complex social behaviors rarely result in death but can cause serious damage and harm in the individual. Moreover, adult crocodilians do not have natural predators - they only have them in early stages, when they are neonates and juveniles (Scott, 2004). For that reason, predation marks on adult crocodilians are extremely rare, even more so in the fossil record. Furthermore, although there have been clear cases of predation and evidence of scavenging in the fossil record (Erickson and Olson, 1996; Chure et al., 1998; Frey et al., 2002; Everhart, 2005; Reisz and Tsuji, 2006; Bianucci et al., 2010; Hone et al., 2010), no recorded cases exist of predation and scavenging on terrestrial fossil crocodyliforms. Therefore, the peirosaurid specimen MUCP-27 represents the first case and demonstrates that large predators - other big crocodyliforms or maybe even theropod dinosaurs - potentially chose other predators of considerable size as prey, such as this three meter long peirosaurid.

\section{Acknowledgments}

I thank J. Calvo for access to the materials at the Comahue University Museum (MUC) to study the crocodyliforms under his care. I am indebted to D. Pol for his constant help and comments on the peirosaurid specimen MUCPv-27, which were very useful for improving this work. I also express gratitude to P. Makovicky, D. Pol, and an anonymous referee for carefully reviewing, criticizing and commenting. In addition, I thanks M.B. Andrade, D. Riff, A. Haro and M. Ezcurra, for their valuable comments and in-depth review of the early manuscript. To R. Juárez Valieri for his help, information, and comments. Thanks are also extensive to Sergio de la Vega and Ivana Amelotti for their constant help.

\section{References}

Albino, A.M. and Caldwell, M.W. 2003. Hábitos de vida de la serpiente cretácica Dinilysia patagonica Woodward. Ameghiniana 40: 407-414.

Alvarenga, H. and Bonaparte, J.F. 1992. A new flightless landbird from the Cretaceous of Patagonia. In: K.E. Campbell (ed.), $P a-$ pers in Avian Paleontology. Natural History Museum of Los Angeles County, Science Series 36, pp. 51-64.

Apesteguía, S. 2004. Bonitasaura salgadoi gen. et sp. nov.: a beaked sauropod from the Late Cretaceous of Patagonia. Naturwissenschaften 91: 493-497.

Avila, L.S., Fernandes, R. and Ramos, D.F.B. 2004. Bite marks on a crocodylomorph from the Upper Cretaceous of Brazil: evidence of social behavior? Journal of Vertebrate Paleontology 24: 971-973.

Barder, K.S., Hasiotis, S.T. and Martin, L.D. 2009. Application of forensic science techniques to trace fossils on dinosaur bones from a quarry in the Upper Jurassic Morrison Formation, Northeastern Wyoming. Palaios 24: 140-158.

Behrensmeyer, A.K. 1978. Taphonomic and ecologic information from bone weathering. Paleobiology 4: 150-162.

Bell, P.R., and Currie, P.J. 2009. A tyrannosaur jaw bitten by a confamilial: scavenging or fatal agonism? Lethaia 43: 278-281.

Benson, R.B.J., Carrano, M.T. and Brusatte, S.L. 2009. A new clade of archaic large-bodied predatory dinosaurs (Theropoda: Allosauroidea) that survived to the latest Mesozoic. Naturwissenschaften 97: 71-78.

Bianucci, G., Sorce, B., Storai, T., and Landini, W. 2010. Killing in the Pliocene: shark attack on a dolphin from Italy. Palaeontology 53: 457-470.

Bonaparte, J.F. 1991. Los vertebrados fósiles de la Formación Río 
Colorado, de la ciudad de Neuquén y cercanías, Cretácico superior, Argentina. Revista del Museo Argentino de Ciencias Naturales 4: 17-123.

Brochu, C.A. 1996. Closure of neurocentral sutures during crocodilian ontogeny: Implications for maturity assessment in fossil archosaurs. Journal of Vertebrate Paleontology 16: 49-62.

Buckley, G.A. and Brochu, C.A. 1999. An enigmatic new crocodile from the Upper Cretaceous of Madagascar. In: D. Unwin (ed.), Cretaceous Fossil Vertebrates. Special Papers in Palaeontology No. 60, pp. 149-175.

Buffetaut, E. 1983. Wounds on the jaw of an Eocene mesosuchian crocodilian as possible evidence for the antiquity of crocodilian intraspecific fighting behavior. Paläontologische Zeitschrift 57: $143-145$

Caldwell, M.W. and Albino, A.M. 2001. Palaeoenviroment and palaeoecology of three Cretaceous snakes: Pachyophis, Pachyrhachis, and Dinilysia. Acta Palaeontologica Polonica 46: 203 218.

Calvo, J.O., Engelland, S., Heredia, S. and Salgado, L. 1997. First record of dinosaur eggshells (?Sauropoda-Megaloolithidae) from Neuquén, Patagonia, Argentina. Gaia 14: 23-32.

Carvalho, I.S. and Bertini, R.J. 1999. Mariliasuchus: um novo Crocodylomorpha (Notosuchia) do Cretáceo da Bacia Bauru, Brasil. Geología Colombiana 24: 83-105.

Carvalho, I.S., Borges Riveiro, L.C. and Avila, L.S. 2004. Uberabasuchus terrificus sp. nov., a new Crocodylomorpha from the Bauru Basin (Upper Cretaceous), Brazil. Gondwana Research 7: 975-1002.

Chiappe, L.M. and Calvo, J.O. 1994. Neuquenornis volans, a new Late Cretaceous bird (Enantiornithes: Avisauridae) from Patagonia, Argentina. Journal of Vertebrate Paleontology 14: 230-246.

Chure, D.J. and Fiorillo, A.R. 1997. "One big al to go and hold the mayo": evidence of scavenging of a specimen of Allosaurus from the Morrison Formation (Late Jurassic) of Wyoming. Journal of Vertebrate Paleontology 17: 38A

Chure, D.J., Fiorillo, A.R. and Jacobsen, A. 1998. Prey bone utilization by predatory dinosaurs in the Late Jurassic of North America, with comments on prey bone use by dinosaurs throughout the Mesozoic. Gaia 15: 227-232.

Coria, R.A. and Arcucci, A.B. 2004. Nuevos dinosaurios terópodos de Auca Mahuevo, Provincia del Neuquén (Cretacico Tardio, Argentina). Ameghiniana 41: 597-603.

Cott, H.B. 1961. Scientific results of an inquiry into the ecology and economic status of the Nile Crocodile (Crocodilus niloticus) in Uganda and Northern Rhodesia. Transactions of the Zoological Society of London 29: 211-356.

de la Fuente, M.S. 2007. Testudines. In: Z. Gasparini, L. Salgado and R.A. Coria (eds.), Patagonian Mesozoic Reptiles, Indiana University Press, Bloomington, pp. 50-86.

Erickson, G.M. and Olson, K.H. 1996. Bite marks attributable to Tyrannosaurus rex: preliminary description and implications. Journal of Vertebrate Paleontology 16: 175-178.

Everhart, M.J. 2005. Bite marks on an elasmosaur (Sauropterygia; Plesiosauria) paddle from the Niobrara Chalk (Upper Cretaceous) as probable evidence of feeding by the lamniform shark, Cretoxyrhina mantelli. PalArch 2: 1-11.

Ezcurra, M.D. and Méndez, A.H. 2009. First report of a derived abelisaurid theropod from the Bajo de la Carpa Formation (Late Cretaceous), Patagonia, Argentina. Bulletin of Geosciences 84: 547-554.

Farlow, J.O. and T.R. Holtz, Jr. 2002. The fossil record of predation in dinosaur. In M. Kowalewski and P.H. Kelley (eds.), The Fossil Record of Predation. The Paleontological Society Papers 8, pp. 251-266.

Fiorelli, L.E. and Calvo, J.O. 2007. The first "protosuchian" (Archosauria: Crocodyliformes) from the Cretaceous (Santonian) of Gondwana. Arquivos do Museu Nacional, Rio de Janeiro 65: 417-459.

Fiorelli, L.E. and Calvo, J.O. 2008. New remains of Notosuchus terrestris Woodward (Crocodyliformes: Mesoeucrocodylia) from
Late Cretaceous (Santonian) of Neuquén, Patagonia, Argentina. Arquivos do Museu Nacional, Rio de Janeiro 66: 83-124.

Fiorelli, L.E., Amelotti, I., Juárez Valieri, R.D. and Salinas, G. 2006. Relaciones paleoecológicas en Norpatagonia hace 80 millones de años. Ameghiniana Suplemento Resúmenes 43: 39R.

Fiorelli, L.E., Pol, D., Porfiri, J.D., Calvo, J.O. and Juárez Valieri, R.D. 2007. Peirosaurid affinities of a crocodyliform from the Bajo de la Carpa Formation, Upper Cretaceous, Neuquén. Ameghiniana Suplemento Resúmenes 44: 94R.

Frey, E., Buchy, M.-C., Stinnesbeck, W. and López-Oliva, J.G. 2002. Geosaurus vignaudi n.sp. (Crocodyliformes: Thalattosuchia), first evidence of metriorhynchid crocodilians in the Late Jurassic (Tithonian) of central-east Mexico (State of Puebla). Canadian Journal of Earth Science 39: 1467-1483.

Garrick, L., Lang, J. and Herzog, H.A. 1978. Social signals of the American alligator. Bulletin of the American Museum of Natural History 160: 155-192.

Garrido, A. 2000. [Estudio estratigráfico y reconstrucción paleoambiental de las secuencias fosilíferas continentales del Cretácico Superior en las inmediaciones de Plaza Huincul, Provincia del Neuquén. Tesis de Licenciatura. Universidad Nacional de Córdoba, Córdoba, Argentina, 133pp. Unpublished.].

Gilmore, C.W. 1946. Notes on recently mounted reptile fossil skeletons in the United States National Museum. Proceedings of the United States National Museum 96: 195-203.

Heredia, S. and Calvo, J.O. 2002. Estratigrafía de las bardas de la ciudad de Neuquén. $15^{\circ}$ Congreso Geológico Argentino (LUGAR), Actas, art. no 196: 7pp.

Hill, A.P. 1987. Damage to some fossil bones from Laetoli. In: M.D. Leakey and J.M. Harris (eds.). Laetoli: A Pliocene Site in Northern Tanzania. Clarendon Press, Oxford, pp. 543-545.

Holz, M. and Simões, M.G. 2005. Taphonomy - Overview of Main Concepts and Applications to Sequence Stratigraphic Análisis. In: E.A.M. Koutsoukos (ed.), Applied Stratigraphy (Topics in Geobiology), Springer, 249-278.

Hone, D., Choiniere, J., Sullivan, C., Xu, X., Pittman, M., and Tan, Q. 2010. New evidence for a trophic relationship between the dinosaurs Velociraptor and Protoceratops. Palaeogeography, Palaeoclimatology, Palaeoecology 291: 488-492.

Huene, F. 1929. Los saurisquios y ornitisquios del Cretácico Argentino. Anales del Museo de La Plata, 2da Serie: 1-194.

Hunt, H. 1977. Aggressive behavior by adult Morelet's crocodiles, Crocodylus moreletii towards young. Herpetologica 33: 195-201.

Irmis, R.B. 2007. Axial skeleton ontogeny in the Parasuchia (Archosauria: Pseudosuchia) and its implications for ontogenetic determination in archosaurs. Journal of Vertebrate Paleontology 27: 350-361.

Jacobsen, A.R. 1999. Feeding behaviour of carnivorous dinosaurs as determined by tooth marks on dinosaur bones. Historical Biology 13: 17-26.

Lapparent de Broin, F. and de la Fuente, M.S. 2001. Oldest world Chelidae (Chelonii, Pleurodira), from the Cretaceous of Patagonia. Comptes Rendues Académie des Sciences de Paris 333: 463470.

Laurenti, J.N. 1768. Specimen medicum, exhibens synopsin reptilium emendatam cum experimentis circa venena et antidota reptilium austracorum, quod authoritate et consensu. Vienna, Joan. Thomae, 217 pp.

Leanza, H.A., Apesteguía, S., Novas, F.E. and de la Fuente, M.S. 2004. Cretaceous terrestrial beds from the Neuquén Basin (Argentina) and their tetrapod assemblages. Cretaceous Research 25: 61-87.

Lecuona, A. and Pol, D. 2008. Tooth morphology of Notosuchus terrestris (Notosuchia: Mesoeucrocodylia): New evidence and implications. Comptes Rendus Palevol. 7: 407-417.

Martinelli, A.G. 2003. New cranial remains of the bizarre notosuchid Comahuesuchus brachybuccalis (Archosauria, Crocodyliformes) from the Late Cretaceous of Río Negro Province (Argentina). Ameghiniana 40: 559-572.

Martinelli, A.G. and Pais, D.F. 2008. A new baurusuchid crocody- 
liform (Archosauria) from the Late Cretaceous of Patagonia (Argentina). Comptes Rendus Palevol. 7: 371-381.

Martinelli, A.G. and Vera, E. 2007. Achillesaurus manazzonei, a new alvarezsaurid theropod (Dinosauria) from the Late Cretaceous Bajo de la Carpa Formation, Río Negro Province, Argentina. Zootaxa 1582: 1-17.

Molnar, R.E. and Farlow, J.O. 1990. Carnosaur paleobiology. In: D.B. Weishampel, P. Dodson and H. Osmólska (eds.), The Dinosauria, University California Press, Berkeley, pp. 210-224.

Njau, J.K. and Blumenschine, R.J. 2006. A diagnosis of crocodile feeding traces on larger mammal bone, with fossil examples from the Plio-Pleistocene Olduvai Basin, Tanzania. Journal of Human Evolution 50: 142-162.

Parras, A. and González Riga, B.J. 2001. Primer registro de dinosaurios saurópodos, procedentes de la Formación Río Colorado (Santoniano-Campaniano temprano), en la provincia de La Pampa, Argentina. Ameghiniana Suplemento Resúmenes 38: 38-39R.

Pol, D. 2005. Postcranial remains of Notosuchus terrestris (Archosauria: Crocodyliformes) from the Upper Cretaceous of Patagonia, Argentina. Ameghiniana 42: 21-38.

Porfiri, J.D. and Calvo, J.O. 2006. A new record of Carnotaurinae (Theropoda: Abelisauridae) from the Upper Cretaceous of Neuquén, Patagonia. $66^{\circ}$ Anual Meeting of the Society of Vertebrate Paleontology, USA, Abstracts: 111A-112A.

Porfiri, J.D., Calvo, J.O., Juárez Valieri, R.D. and Santos, D.D. 2008. A new large theropod dinosaur from the Bajo de la Carpa Formation (Late Cretaceous) of Neuquén, Patagonia. $3^{\circ}$ Congreso Latinoamericano de Paleontología de Vertebrados (LUGAR), Resúmenes: 202

Pough, F.H., Andrews, R.M., Cadle, J.E., Crump, M.L., Savitzky, A.H. and Wells, K.D. 1998. Herpetology. Prentice Hall, Upper Sadle River, 577 pp.

Price, L.I. 1945. A new reptile from the Cretaceous of Brazil. Notas Preliminares e Estudos, Servicio Geologia Mineralogia do Brasil 25: $1-8$.

Price, L.I. 1950. On a new crocodilian, Sphagesaurus, from the Cretaceous of the State of São Paulo, Brazil. Anais Academia Brasilera de Ciencias 22: 77-83.

Price, L.I. 1959. Sôbre um crocodilídeo Notossúquio do Cretácico Brasileiro. Boletim do Departamento Nacional da Produçao Mineral, Divisao de Geologia e Mineralogia, Rio de Janeiro 188: 755.

Reisz, R.R. and Tsuji, L.A. 2006. An articulated skeleton of Varanops with bite marks: the oldest known evidence of scavenging among terrestrial vertebrates. Journal of Vertebrate Paleontology 26: 1021-1023.

Sanchez, M.L.; Gómez, M.J. and Heredia, S. 2006. Sedimentología y paleoambientes del subgrupo Río Colorado (Cretácico Superior), Grupo Neuquén, en las bardas de la ciudad de Neuquén y alrededores. Revista de Asociación Geológica Argentina 61: 236255.

Sawyer, G.T. and Erickson, B.R. 1998. Paleopathology of the Paleocene crocodile Leidyosuchus (=Borealosuchus) formidabilis. Monograph, Vol. 4: Monograph of the Science Museum of Minnesota Paleontology, St. Paul, 38 pp.

Schweitzer, M.H., Jackson, F.D., Chiappe, L.M., Schmitt, J.G., Calvo, J.O. and Rubilar, D.E. 2002. Late Cretaceous avian eggs with embryos from Argentina. Journal of Vertebrate Paleontology 22: 191-195.
Scott, C. 2004. Endangered and Threatened Animals of Florida and Their Habitats. University of Texas Press, 386 pp.

Senter, P. 2008. Homology between and antiquity of stereotyped communicatory behaviors of crocodilians. Journal of Herpeto$\log y$ 42: 354-360.

Sereno, P.C. and Novas, F.E. 1993. The skull and neck of the basal theropod Herrerasaurus ischigualastensis. Journal of Vertebrate Paleontology 13: 451-476.

Smith, R.H. 1993. Vertebrate taphonomy of Late Permian floodplain deposits in the southwestern Karoo Basin of South Africa. Palaios 8: 45-67.

Tanke, D. and Currie, P.J. 1998. Head-biting behavior in theropod dinosaurs: paleopathological evidence. Gaia 15: 167-184.

Thorbjarnarson, J.B. and Hernández, G. 1993. Reproductive ecology of the Orinoco crocodile (Crocodylus intermedius) in Venezuela. II: Reproductive and social behavior. Journal of Herpetology 27: 371-379.

Vliet, K.A. 1989. Social displays of the American alligator (Alligator mississippiensis). American Zoologist 29: 1019-1031.

Vliet, K.A. 2001a. Reproductive Biology of Crocodilians. Chapter 4. In: J. Groves and K.A. Vliet (eds.). Crocodilian Biology and Captive Management. A monograph to accompany the AZA Professional Training Program, St. Augustine, Florida, 34 pp.

Vliet, K.A. 2001b. Social Behavior of Crocodilians. Chapter 12. In: J. Groves and K.A. Vliet (eds.). Crocodilian Biology and Captive Management. A monograph to accompany the AZA Professional Training Program, St. Augustine, Florida, 19 pp.

Weigelt, J. 1989. Recent Vertebrate Carcasses and their Paleobiological Implications, translated from Rezente Wirbeltierleichen und ihre palaöbiologische Bedeutung (1927) by J. Schaeffer: University of Chicago Press, Chicago, 187 p.

Willis, B.J. and Behrensmeyer, A.K. 1994. Architecture of Miocene overbank deposits in northern Pakistan. Journal of Sedimentary Research 64: 60-67.

Woodward, A.S. 1896. On two Mesozoic crocodilians Notosuchus (genus novum) and Cynodontosuchus (genus novum) from the Red Sandstones of the Territory of Neuquén (Argentina Republic). Anales del Museo de La Plata, Paleontología 4: 1-20.

Woodward, A.S. 1901. On some extinct reptiles from Patagonia of the genera Miolania, Dinilysia and Genyodectes. Proceedings of the Zoological Society of London 1: 169-184.

Recibido: 11 de mayo de 2009.

Aceptado: 23 de abril de 2010 . 